\title{
Identifikasi Pseudomonas aeruginosa dan tes sensitivitas siprofloksasin pada abses periodontal Identification of Pseudomonas aeruginosa and sensitivity test of ciprofloxacin
on periodontal abcess
}

\author{
${ }^{1}$ Irene E. Rieuwpassa, ${ }^{2}$ Muliaty Yunus, ${ }^{3}$ I Wayan Suka Arsana \\ ${ }^{1}$ Bagian Biologi Oral \\ ${ }^{2}$ Bagian Radiologi \\ Fakultas Kedokteran Gigi Universitas Hasanuddin \\ ${ }^{3}$ Departemen Bedah Umum RS Labuang Baji \\ Makassar, Indonesia
}

\begin{abstract}
Periodontitis is a common type of periodontal disease caused by expansion of the early stages of gingival inflammation. Expansion of inflammation to the tissue structures supporting the teeth can be modified by the pathogenic ability of plaque or host resistance factors. A total of 200 different bacteria have been identified on the plaque. Resistance to antimicrobials can be natural because the microbes develop mechanisms to defend themselves. Ciprofloxacin is a synthetic drug of the second generation quinolones derivatives. Mechanism of its action is to inhibit the activity of bacterial DNA gyrase, which is bactericidal with a broad spectrum against Grampositive or negative. This observational study identified P. aeruginosa and sensitivity test was performed to ciprofloxacin in periodontal abscesses. Study conducted in 23 patients with periodontal abscess. Of those, Pseudomonas was acquired for 8 samples and 4 of them was resistant to ciprofloxacin.
\end{abstract}

Key words: sensitivity test, ciprofloxacin, periodontal abscess

\begin{abstract}
ABSTRAK
Periodontitis adalah jenis umum penyakit periodontal yang disebabkan oleh perluasan radang yang berawal dari gingiva. Perluasan radang ke struktur jaringan pendukung gigi dapat dimodifikasi oleh kemampuan patogenik dari plak atau faktor resistensi host. Sebanyak 200 jenis bakteri yang berbeda telah diidentifikasi pada plak. Resistensi terhadap antimikroba adalah hal alami karena mikroba mengembangkan mekanisme pertahanan diri. Siprofloksasin adalah agen generasi kedua, dan merupakan salah satu obat sintetik derivat quinolon. Mekanisme kerjanya adalah menghambat aktivitas DNA gyrase bakteri, bersifat bakterisidal dengan spektrum luas terhadap bakteri Gram-positif maupun negatif. Penelitian observasional ini mengidentifikasi bakteri P.aeruginosa dan tes sensitivitas terhadap siprofloksasin pada abses periodontal. Dari 23 sampel penderita abses periodontal diperoleh 8 sampel P.aeruginosa, $4(50 \%)$ di antaranya resisten terhadap siprofloksasin. Disimpulkan bahwa akibat penggunaan antibiotik yang irasional, saat ini mulai berkembang resistensi bakteri Gram-negatif yang dahulu dapat diatasi oleh siprofloksasin.
\end{abstract}

Kata kunci: tes sensitivitas, siprofloksasin, abses periodontal

Koresponden: Irene E. Rieuwpassa, Bagian Biologi Oral Fakultas Kedokteran Gigi Universitas Hasanuddin, Jl. Perintis Kemerdekaan Km.10, Makassar 90245.E-mail:drgirene@yahoo.com

\section{PENDAHULUAN}

Kebanyakan infeksi pada rongga mulut bersifat polimikrobial. Akumulasi metabolisme bakteri pada permukaan jaringan keras mulut dianggap sebagai penyebab primer periodontitis. Akumulasi bakteri pada gigi merangsang respon inflamasi secara reversibel pada jaringan gingiva. Jaringan yang mengalami inflamasi akhirnya dapat mengalami destruksi secara permanen. Spesies subgingiva tertentu kebanyakan terdiri dari bakteri Gram-negatif yang dihubungkan dengan etiologi penyakit periodontal destruktif, seperti A.actinomycetemcomitans, P.gingivalis, Provotella intermedia dan beberapa spesies bakteri lainnya. ${ }^{1}$
Periodontitis menjadi salah satu penyakit infeksi kronis rongga mulut yang sering terjadi dalam kesehatan masyarakat. Di Amerika Serikat, 7 dari 10 orang menderita periodontitis. Jika didasarkan pada attachment loss (AL) $>2 \mathrm{~mm}, 85 \%$ orang dewasa dan 90\% usia 55-64 tahun menderita penyakit ini. Sementara di Cina, periodontitis menyerang 58\% kelompok usia 3545 tahun, dan 94\% kelompok usia 65-74 tahun. ${ }^{2.3}$

Sejak siprofloksasin dikembangkan, obat ini telah memperlihatkan tingkat aktivitas perlawanan terhadap bakteri anaerob. Siproflosasin pada awalnya dikembangkan karena aktivitasnya terhadap bakteri Gram-negatif, tetapi terebatas aktivitasnya terhadap organisme Gram-positif. 
Siprofloksasin paling aktif terhadap Gram-negatif, terutama Pseudomonas aeruginosa. ${ }^{4}$

Antibiotik yang sering digunakan pada infeksi P.aeruginosa adalah penisilin yang dikombinasi dengan aminoglukosida, aztreonam, imipenem, quinolon, termasuk siprofloksasin. Siprofloksasin merupakan agen generasi kedua, salah satu obat sintetik derivat quinolon. Mekanisme kerjanya adalah menghambat aktivitas DNA gyrase bakteri, bersifat bakterisid dengan spektrum luas terhadap bakteri Gram-positif maupun negatif. Siprofloksasin efektif digunakan untuk infeksi saluran kemih, uretritis, demam tifoid dan paratifoid, infeksi saluran napas, infeksi jaringan lunak serta osteomielitis. Obat ini dapat juga digunakan sebagai antimikroba profilaksis pada penderita netropenia. Walaupun obat ini dapat bermanfaat pada eksaserbasi fibrisis kistik akibat Pseudomonas, kurang lebih sepertiga dari organisme mukoid semacam ini bersifat resisten. ${ }^{5}$

Tujuan penelitian ini dilakukan untuk membuktikan keberadaan P.aeruginosa dari sampel abses periodontal dan melakukan uji sensitivitas terhadap antibiotik siprofloksasin.

\section{METODE PENELITIAN}

Penelitian observasi laboratorium ini dilakukan di Rumah Sakit Gigi dan Mulut Halimah Dg. Sikati Fakultas Kedokteran Gigi, dan Laboratorium Mikrobiologi Fakultas Kedokteran Universitas Hasanuddin.

\section{Identifikasi}

Untuk mengidentifikasi bakteri, digunakan agar McConkey, pewarna Gram, reagen untuk uji biokimia, reagen untuk uji bakteri non-fermenter (oksidase, pyocianin, fluoresens, glukosa, xylosa, manitol, laktosa, maltosa, eskulin, urea, D Nase, ONPG, indol, motility, flagella), nutrien agar (NA) (Difco), cakram kertas yang mengandung siprofloksasin.

Sebanyak 23 sampel berupa pus diambil dengan cara swab menggunakan kapas lidi. Setelah itu, kapas lidi dimasukkan dalam media transpor, lalu spesimen diinokulasi ke dalam media blood agar dan diinkubasi pada suhu 35$37^{\circ} \mathrm{C}$ selama 24 jam. Pada koloni dilakukan uji pewarnaan Gram untuk menemukan bakteri Gram-negatif. Hasil bakteri Gram-negatif batang dilanjutkan dengan uji biokimia untuk menemukan bakteri yang fermenter atau nonfermenter. Bakteri yang termasuk golongan nonfermenter diamati sesuai dengan tabel Connie
Mohan dalam National Committee for Clinical Laboratory Standard (NCCLS). ${ }^{6}$

\section{Uji difusi cakram}

Inokulum disiapkan dengan menggunakan kapas lidi steril atau sengkelit. Diambil 3-5 koloni hasil isolasi spesimen klinik dan disuspensi ke dalam tabung berisi larutan $\mathrm{NaCl}$ fisiologis steril 5 $\mathrm{ml}$, kemudian kapas lidi bekas pakai dibuang ke dalam larutan hipoklorit 2\%. Hasil suspensi bakteri dibandingkan dengan standar kekeruhan McFarland 0,5.

Kapas lidi dicelupkan ke dalam suspensi bakteri dan diputar beberapa kali kemudian ditekan-tekan pada dinding tabung untuk membuang kelebihan inokulum. Kapas lidi yang mengandung inokulum dihapuskan secara merata pada permukaan agar Mueller Hinton, kemudian cawan petri ditutup dan dibiarkan selama 3-5 menit.

Cakram kertas yang berisi siprofloksasin diletakkan pada permukaan agar Mueller Hinton dan sedikit ditekan agar melekat sempurna dan tidak bergeser, kemudian didiamkan selama 15 menit. Setelah itu diinkubasi pada suhu $35-37^{\circ} \mathrm{C}$ selama 16-20 jam dalam posisi cawan terbalik. Hasil diperoleh dengan mengukur zona hambatan yang terbentuk pada agar, dan lebar zona hambat dibandingkan dengan tabel standar NCCLS, untuk menentukan hasil isolat bakteri tersebut resisten, intermediat atau sensitif. Disk $5 \mu \mathrm{g}$ dengan kategori kuman resisten $\leq 5$, intermediat $16-20$, sensitif $\geq 21{ }^{6}$

\section{HASIL}

Dari 23 sampel yang diperiksa, ditemukan $P$. aeruginosa pada 8 sampel. P.aeruginosa paling banyak diperoleh dari swab penderita abses periodontal. Parameter yang digunakan dalam penelitian ini adalah lebar zona hambatan yang terbentuk dari masing-masing disk antibiotik (gambar 1), dibandingkan dengan lebar zona hambat standar menurut NCCLS. Empat dari delapan sampel (50\%) P.aeruginosa yang resisten terhadap siprofloksasin (tabel 1).

Pada pengujian sensitivitas dengan cara difusi cakram akan terlihat zona hambatan di sekitar paper disc yang mengandung siprofloksasin. Zona bening di sekeliling obat dianggap sebagai ukuran kekuatan hambatan obat terhadap organisme. Hasil pengukuran diameter zona hambatan menunjukkan sampel yang sensitif dan resisten terhadap siprofloksasin, masing-masing 4 sampel. 

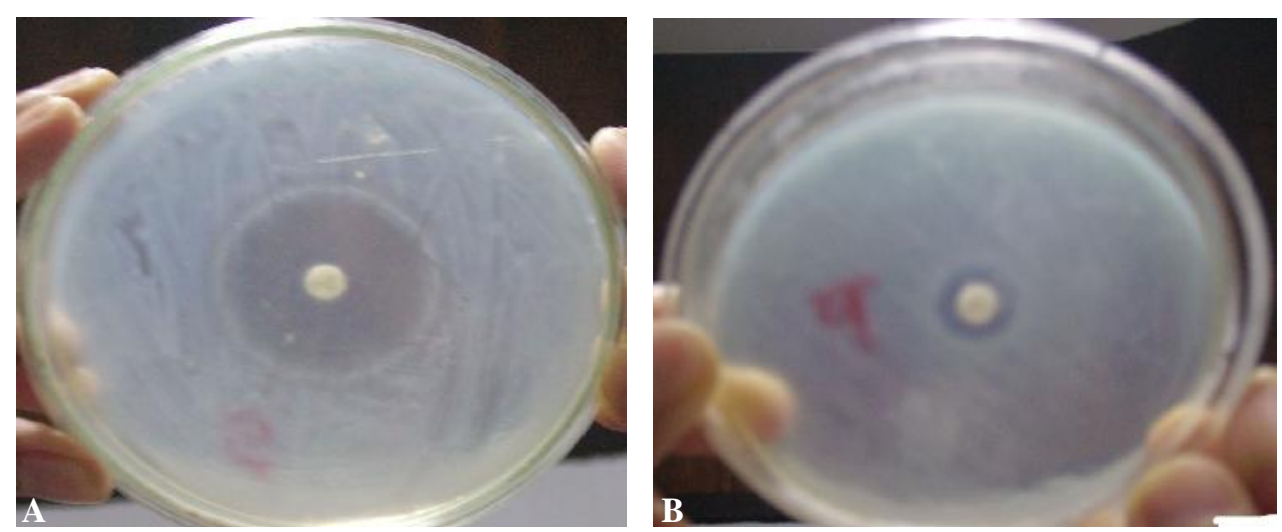

Gamar 1. A. Hasil isolat P.gingivalis yang sensitif terhadap siprofloksasin; B. hasil isolat P.aeruginosa yang resisten terhadap siprofloksasin

Tabel 1. Hasil uji difusi cakram $P$. aeruginosa

\begin{tabular}{ccc}
\hline Sampel & $\begin{array}{c}\text { Zona Hambatan } \\
(\mathrm{mm})\end{array}$ & Kriteria \\
\hline 1 & 8 & Resisten \\
2 & 12 & Resisten \\
3 & 8 & Resisten \\
4 & 8 & Resisten \\
5 & 28 & Sensitif \\
6 & 24 & Sensitif \\
7 & 26 & Sensitif \\
8 & 36 & Sensitif \\
\hline
\end{tabular}

\section{PEMBAHASAN}

Dari penelitian ini, terhadap 23 sampel terdiagnosis abses periodontal dan terbukti bahwa ditemukan sebanyak 8 sampel diidentifikasi sebagai P.aeruginosa. Hal ini memberi gambaran bahwa infeksi periapikal dapat menyebabkan periodontitis sesuai dengan penelitian yang dilakukan oleh Nord dkk yang menemukan P.aeruginosa dari penderita terdiagnosis periodontitis apikalis, pulpa nekrosis, pulpitis, dan alveolitis maksilaris. Pada penelitian ini, P.aeruginosa paling banyak diperoleh dari soket gigi atau daerah akar gigi penderita abses periodontal yang diambil segera setelah pencabutan gigi. Metode ini sudah dilakukan dalam penelitian sebelumnya dalam mengisolasi dan mengidentifikasi Porphyromonas gingivalis pada penderita periodontitis kronis. ${ }^{7-9}$

Tes difusi cakram adalah metode umum yang digunakan untuk mengetahui resistensi dan sensitivitas kuman terhadap penggunaan obat, dengan waktu uji yang diperlukan kurang lebih satu minggu. Metode ini dilakukan untuk mengetahui adanya zona hambatan yang terbentuk. Hasil pengukuran diameter zona hambatan menunjukkan apakah kuman resisten atau sensitif terhadap suatu antibiotik. Zona hambatan yang terbentuk dibandingkan dengan tabel standar NCCLS, disk $5 \mu 1$ dengan kategori resisten, intermidiat dan sensitif. Jika strain P.aeruginosa tidak mengalami mutasi pada target kerja obat maka strain ini akan sensitif terhadap antibiotik.

Pada penelitian ini zona bening terjadi karena siprofloksasin bekerja pada target yang sesuai dan juga menghambat pertumbuhan P.aeruginosa. Target obat pada topoisomerase II (gyrase A) sebagai target utama dan merupakan mekanisme kerja dari siprofloksasin. Siprofloksasin menyekat sintesis DNA bakteri dengan jalan menghambat topoisomerase II pada bakteri. Penghambatan DNA gyrase akan mencegah relaksasi supercoiled DNA secara positif yang dibutuhkan untuk transkripsi dan replikasi normal. ${ }^{5,10,11}$

Hampir semua penentuan resistensi bakteri terhadap antibiotik dilakukan dengan uji difusi cakram. Untuk melakukan pengujian ini, terlebih dahulu bakteri harus diisolasi, dimurnikan dan selanjutnya dipaparkan pada antibiotik. Cara ini mempunyai kelemahan, khususnya dalam hal lamanya waktu untuk mendapatkan hasil. Oleh karena itu, dalam penelitian ini perlu dilakukan identifikasi dan deteksi adanya mutasi gen dengan metode PCR sehingga dapat diperoleh hasil yang akurat dan dengan waktu yang singkat.

Bila dibandingkan dengan penelitian sebelumnya, yaitu hubungan antara mutasi gen topoisomerase II (gyrase A) dengan tes resistensi terhadap siprofloksasin menggunakan metode disc diffusion yang dilanjutkan dengan RFLP-PCR pada P.aeruginosa penderita abses lain memperlihatkan adanya mutasi pada sampel yang resisten. Pada penelitian yang sejenis di Korea, dari 102 mutasi, sejumlah $101(98,1 \%)$ terjadi 
pada gyrase A. Sampel resisten sebanyak 11 namun hanya 6 yang terlihat bermutasi disebabkan ekspresi mutasi gen tidak didapatkan pada gyrase $\mathrm{A}$, kemungkinan pada gyrase $\mathrm{B}, \operatorname{par} \mathrm{B}$ atau par $\mathrm{C}$. Hal ini terlihat pula pada penelitian sebelumnya di Korea bahwa dapat terjadi mutasi tunggal maupun ganda pada gyrase A, gyrase B, atau pada par B dan par C. ${ }^{12,13}$ Pseudomonas aeruginosa telah memperlihatkan penurunan sensitivitas fluoroquinolon dari yang seharusnya, yaitu perubahan jenis Thr-83 menjadi Ile dan Asp-87 menjadi Asn pada gyrase A, perubahan jenis Ser87 menjadi Leu pada par $\mathrm{C}$ dan par E Asp 419 menjadi Asn. $^{13,14}$

Berdasarkan hasil penelitian di Paris, 984 strain bakteri yang diisolasi dari sampel urin dan dilakukan uji sensitivitas, hasilnya ditemukan $30 \%$ P.aeruginosa resisten terhadap siprofloksasin. Hasil penelitian Lee dan Lee memperlihatkan dari 102 mutasi yang terjadi, terdapat $101(98,1 \%)$ substitusi Thr-83 menjadi Ile pada gyrase A. Mutasi gyrase A pada P.aeruginosa posisi Thr-83 (ACC menjadi ATC), Asn-87 (GAC menjadi AAC) dan Gln-106 (CAG menjadi AAC). Dengan menggunakan primer yang sama dilaporkan bahwa perubahan asam amino pada gyrase A merupakan mutasi utama untuk resistensi siprofloksasin pada P.aeruginosa. ${ }^{13-15}$

Pada P.aeruginosa selain mutasi pada topoisomerase II dan topoisomerase IV, ditentukan juga oleh keterpaparan efflux pumps menyebabkan resistensi obat terhadap siprofloksasin. Keterpaparan awal terhadap fluoroquinolon mempengaruhi efflux pumps yang terpapar secara berlebihan dibandingkan mutasi pada daerah target. Dijelaskan pula bahwa resistensi pada kadar yang rendah oleh efflux pumps yang terpapar secara berlebihan terjadi pada proses awal dan resistensi pada kadar yang tinggi oleh daerah target mutasi terjadi pada proses selanjutnya. Untuk mengevaluasi keterpaparan efflux pumps dengan cara menghitung nilai total RNA dari resistance nodulation cell division (RND) yang merupakan keluarga dari efflux pumps (mex $\mathrm{B}$, mex $\mathrm{D}$, mex $\mathrm{F}$, mex I dan mex Y menggunakan Real-Time PCR. Penelitian ini dilakukan di Hyogo, Jepang pada 17 bakteri yang diisolasi dari Rumah Sakit Universitas Kobe. Namun tidak ditemukan hubungan antara jumlah gen tersebut dengan MIC terhadap siprofloksasin pada semua sampel. ${ }^{14}$

Diketahui bahwa keterpaparan efflux pumps telah dideteksi dan 7 jenis diantaranya telah diketahui mekanismenya dalam resistensi terhadap obat. Yoneda dkk melaporkan bahwa jumlah RND efflux pumps dihitung dengan metode Western blotting dikorelasikan dengan jumlah mRNA dari lesi yang dihitung dengan Real-Time PCR dan metode selanjutnya, digunakan untuk mengevaluasi keterpaparan jenis pumps sebab kecepatan dan tingkat sensitivitas yang sangat tinggi. ${ }^{14}$

\section{SIMPULAN}

Dari penelitian mengenai identifikasi Pseudomonas aeruginosa dan tes sensitivitas siprofloksasin pada abses periodontal disimpulkan bahwa akibat penggunaan antibiotik yang irasional, saat ini mulai berkembang resistensi bakteri Gram-negatif yang dahulu dapat diatasi dengan baik oleh siprofloksasin.

\section{SARAN}

Teknik PCR dapat direkomendasikan untuk deteksi bakteri Gram-negatif anaerob, karena dengan cara kultur memerlukan waktu lama. Untuk itu perlu adanya penelitian untuk melihat mutasi gen gyrase yang merupakan sasaran kerja antibiotik siprofloksasin pada $P$. aeruginosa.

\section{DAFTAR PUSTAKA}

1. Ronderos M, Michalowicz B, Camara R, Contreras A. Bacterial and viral risk markers for juvenile periodontitis. J Periodontol 2000; 71: 1208

2. Burt BA. Epidemiology of periodontal disease. J Periodontol 1996; 67:935-45.

3. Corbert EF, Wong MCM, Lin HC. Periodontal attachment loss in adult in Guandong RRC. J Dent Res 1997; 5: 1176-50.

4. Eick S, Schmitt A, Sachse S. In vitro antibacterial activity of fluoroquinolones against Porphyromonas gingivalis strains. J Antimicrob Chemother 2004; 54(2): 553-6.

5. Brooks GF, Butel SJ, Morse SA. Mikrobiologi Kedokteran. Editor: Elferra RN. Alih bahasa: Hertanto H. Jakarta: Salemba Medika; 2007.

6. Depkes RI. Standar operating procedure (SOP) in microbiology. Jakarta: Laboratoriun Kesehatan Departemen Kesehatan; 2000.

7. Nord CE, Sjoberg L, Wadstrom T. Pseudomonas aeruginosa in oral Infections. Acta Odontol Scand 1972; 30: 371-81.

8. Sweeney LC, Dave J. Antibiotic resistance in general dental practice - a cause for concern? J Antimicrob Chemother 2004; 53(4): 567-76.

9. Rieuwpassa I.E, Hatta M. Deteksi mutasi gen gyrase A Porphyromonas gingivalis resisten terhadap ciprofloxacin berdasarkan teknik Polymerase Chain Reaction. Jurnal Kedokteran YARSI 2010; 17: 11-20. 
10. Axelrod P, Tronstad L, Slots J. Ciprofloxacin treatment of periapical Pseudomonas aeruginosa infection. Philadelphia: Department of Endodontics; 1988.

11. Kim Y, Baik H. Topoisomerase II and topoisomerase iv gene mutations fluoroquinolone resistance of Pseudomonas aeruginosa. J Exp Biomed Sci 2004; 10: 507-14.

12. Rieuwpassa IE, Ruslin M. Correlation between mutation in gene topoisomerase II (gyrase A) with ciprofloxacin resistance test in Pseudomonas aeruginosa. Abstract book of Asian Congres Oral \& Maxillofacial Surgery IX, Malaysia, November 2528, 2010.

13. Lee JK, Lee YS, Park YK, Kim BS. Alterations in the GyrA and GyrB subunits of topoisomerase II and the ParC and ParE subunits of topoisomerase
IV in ciprofloxacin-resistant clinical isolates of Pseudomonas aeruginosa. Int J Antimicrob Agents 2005; 25: 290-5.

14. Ito J, Shirakawa T, Hatta M, Kinoshita S, Gotoh A, Kawabata M. Relationship between expression of multi-component type of efflux pumps, mutations in topoisomerase II and IV, and drug resistance to ciprofloxacin in Pseudomonas aeruginosa. BMC Research. 2006

15. Gabastou JM, Chouaki T, Mangeot J, Zemir A, Manuel C, Lepitre M, dkk. Phenotypes of resistance to antibiotics of the most frequently isolated strains in five specialized hospital centers. Multicenter study. Pathol Biol 1995; 43 (4): 320-3. Available from: http://www.ncbi.nlm.nih.gov/ entrez/query.fcgi?cmd=Retrieve $\& \mathrm{db}=$ PubMed\&list. Diakses 31 Mei 2006. 